\title{
State Regulation of Ribes to Control White Pine Blister Rust
}

Steven M cKay

\begin{abstract}
AdDITIONAL INDEX WORDS. gooseberries, currants, cultivated, $R$ ibes, $C$. ribi cola
Summary. Recent interest in expanding commercial currant and gooseberry (R ibes L.) plantings in the U nited States has put pressure on the states with $R$ ibes restrictions to review their regulations. A meeting on $9 \mathrm{~J}$ anuary 1998 initiated discussion between the state agriculture regulatory agencies, forest pathologists, and horticulturists. Since then a white pine blister rust (WPBR), Cronartium ribicola J.C. Fischer) World Wide Web (Web) site (M cKay, 1998) and list serve have been activated to facilitate communication. Vermont is a state that has no regulations on the books at this time. Connecticut and $\mathrm{N}$ ew York also have mentioned that infection rates are low. $M$ aine retains a $R$ i bes reduction program, and $M$ assachusetts is strictly enforcing their regulations. The following summarizes the general consensus among the majority of regulating states: 1 ) It is desirable to find a way for both white pines (Pinus L.) and commercial R ibes plantings to coexist. 2) M ore research is needed to survey existing $R$ i bes and pines, the potential impact of commercial plantings versus the impact of existing R ibes, and the potential impact of escape / volunteer seedlings from immune R ibes cultivars. 3) There is interest in permitting immune $R$ ibes cultivars to be planted. 4) There is interest in having consistency in regulations from state to state.
\end{abstract}

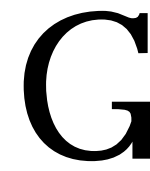

lobalization of the processed and fresh fruit market has placed pressure on U .S. growers to seek crop alternatives and to diversify their businesses. $\mathrm{R}$ ibes crops are one choice of interest since they are not widely cultivated in the U S at this time. U ntil now many producers have focused on local markets and are growing a few hundred plants to satisfy local demand. A few producers have successfully expanded to plantings of 2 ha ( 4.9 acres) or more, and have interest in making further increases.

Some state regulators have reported an increase in inquiries related to $\mathrm{R} i$ bes and complaints from growers that the regulations might be outdated. Typical questions and comments included the following. 1) We have heard that white pine weevils (Pissodes strobi Peck) cause more economic damage than WPBR. 2) There are so many wild $\mathrm{R}$ ibes in the forest already that a commercial planting would not make a significant difference in the incidence of disease. 3) The rust seems to be spreading in the Western N orth America, but may be reaching a naturalization in Eastern N orth America. 4) U se a planting buffer of over $100 \mathrm{~m}(328 \mathrm{ft}$ ) between commercial $\mathrm{R}$ ibes plantings and pines. 5) The rust can be controlled by pruning of pines. 6) The rust can be controlled by resistant pines and immune $\mathrm{R}$ ibes cultivars. Cooperative extension offices have received similar inquiries as well as requests for technical information. This led to a literature search and polling of foresters, horticulturists, pathologists, and regulators to see if there was any consensus regarding the threat of $\mathrm{R}$ ibes to pines because of their role as an intermediate host to WPBR. 


\begin{tabular}{|c|c|c|c|c|c|c|}
\hline State & $\begin{array}{l}\text { Ribes } \\
\text { prohibited }\end{array}$ & $\begin{array}{l}\text { Black } \\
\text { currants } \\
\text { prohibited }\end{array}$ & $\begin{array}{l}\text { Red } \\
\text { currants } \\
\text { and } \\
\text { gooseberries } \\
\text { permitted }\end{array}$ & $\begin{array}{l}\text { State } \\
\text { permits } \\
\text { required }\end{array}$ & $\begin{array}{l}\text { White } \\
\text { pine } \\
\text { blister } \\
\text { rust } \\
\text { immune } \\
\text { varieties } \\
\text { permitted? }\end{array}$ & $\begin{array}{l}\text { R eview } \\
\text { of } \\
\text { regulations } \\
\text { ongoing }\end{array}$ \\
\hline M assachusetts & \multirow{3}{*}{ Yes } & Yes & Yes, in part & Yes & & \\
\hline Michigan & & Yes, in part & Yes, in part & Yes, tentatively & Yes & \\
\hline M ontana & & Yes & Yes & & & \\
\hline N ew H ampshire & \multirow[t]{3}{*}{ Yes } & & & & Yes & \\
\hline N ew Jersey & & Yes & Yes, in part & & & \\
\hline N ew York & & Yes, in part & Yes, in part & & & Yes \\
\hline Rhode I sland & \multirow[t]{4}{*}{ Yes } & & & Yes & & \\
\hline South Carolina & & Yes, in part & Yes, in part & & & \\
\hline Virginia & & Yes & & & & \\
\hline West Virginia & & Yes & Yes, in part & & & \\
\hline
\end{tabular}

zIn part refers to the states permitting cultivation or prohibiting cultivation in specific counties or regions.

T able 2. Personnel responsible for state agricultural regulations of white pine blister rust.

\begin{tabular}{|c|c|}
\hline$\underline{\text { State }}$ & State Agriculture D epartment C ontact \\
\hline D elaware & $\begin{array}{l}\text { Randy Ciurlino } \\
\text { Senior Entomologist } \\
\text { D elaware D epartment of Agriculture } \\
2320 \text { S. D uPont H ighway } \\
\text { D over, DE } 19901-5515 \\
\text { (302) 739-4811 } \\
\text { randy@smtp.dda.state.de.us }\end{array}$ \\
\hline M aine & $\begin{array}{l}\text { Ann G ibbs } \\
\text { State H orticulturalist } \\
\text { M aine D epartment of Agriculture } \\
28 \text { State H ouse Station } \\
\text { Augusta, M E } 04333 \\
\text { (207) 287-3891 } \\
\text { ann.gibbs@state.me.us }\end{array}$ \\
\hline M assachusetts & $\begin{array}{l}\text { Phyllis M ichalewich } \\
\text { Plant Pests } \\
\text { M assachusetts D epartment of Food and Agriculture } \\
100 \text { Cambridge Street } \\
\text { Boston, M A } 02202 \\
\text { (617) 626-1801 } \\
\text { pmichalewich@state.ma.us }\end{array}$ \\
\hline M ichigan & $\begin{array}{l}\text { Gary King } \\
\text { Plant Industry Section M anager } \\
\text { M ichigan D epartment of Agriculture } \\
\text { P.O. Box } 30017 \\
\text { Lansing, M I } 48909 \\
\text { (517) 373- } 9747 \\
\text { kingg1@state.mi.us }\end{array}$ \\
\hline M ontana & $\begin{array}{l}\text { D avid M. T aylor } \\
\text { M ontana D epartment of Agriculture } \\
\text { Agricultural Sciences D ivision } \\
\text { P.O. Box } 200201 \\
\text { H elena, M T 59620-0201 } \\
\text { (406) 444-3730 } \\
\text { dtaylor@mt.gov }\end{array}$ \\
\hline
\end{tabular}

The varied and inconsistent responses to the investigation led to a meeting on 9 January 1998 to get representatives from all the stakeholdersgroupsaround atableto discussthe issue, to update the group on what knowledge we have, what is being researched, and what is lacking.

The consensus of the group was that they would like to see both pines and $\mathrm{R}$ ibes continue development as commercial crops. $\mathrm{R}$ ibes regulated states varied in their statusand interest in changing regulations as well as their desirefor mored efinitiveresearch data. Also the situation with WPBR in the eastern N orth A merica versus western $\mathrm{N}$ orth A mericaisgenerally recognized as different. Following is a summary of the points in question that need research before regulators would feel comfortable changing restrictions: 1 ) A survey of wild Ribes and pines is necessary to document the extent of WPBR, and the susceptibility of plants in the wild. 2) $\mathrm{H}$ ow long can immune $R$ ibes cultivars be expected to remain immune, and what effect if any will their escape into the wild have on the rust's evolution? 3) $\mathrm{H}$ as naturalization of WPBR occurred in Eastern North America? 4) How different are the eastern $\mathrm{N}$ orth American and western $\mathrm{N}$ orth American races of rust, and is there a danger of them penetrating outside their home areas? A re immune 
T able 2. Continued.

\begin{tabular}{|c|c|}
\hline State & State Agriculture D epartment C ontact \\
\hline \multirow[t]{6}{*}{$\mathrm{N}$ ew $\mathrm{H}$ ampshire } & Tom D urkis \\
\hline & $\mathrm{N}$ ew $\mathrm{H}$ ampshire D epartment of Agriculture \\
\hline & State $L$ ab Building \\
\hline & $6 \mathrm{H}$ azen D rive \\
\hline & Concord, NH 03301 \\
\hline & (603) 271-2561 \\
\hline \multirow[t]{7}{*}{ N ew Jersey } & Carl Schultze J r. \\
\hline & $\mathrm{N}$ ew J ersey D epartment of Agriculture \\
\hline & Division of Plant Industry \\
\hline & P.O. Box 330 \\
\hline & Trenton, NJ 08625-0330 \\
\hline & (609) 292-5442 \\
\hline & agpschu@ag.state.nj.us \\
\hline \multirow[t]{7}{*}{ New York } & M ike Birmingham \\
\hline & NYS DEC \\
\hline & Bureau of Forest Resources \\
\hline & 50 Wolfe Road, Room 424 \\
\hline & Albany, NY 12233-4253 \\
\hline & (518) 457-7370 \\
\hline & mjbirmin@gw.dec.state.ny.us \\
\hline \multirow{7}{*}{ N orth Carolina } & Suzanne Spencer \\
\hline & Plant Pathologist \\
\hline & N orth Carolina D epartment of Agriculture \\
\hline & P.O. Box 27647 \\
\hline & Raleigh, NC 27611 \\
\hline & (919) 733-0461 \\
\hline & suzanne.spencer@ncmail.net \\
\hline \multirow[t]{6}{*}{ O hio } & $\mathrm{D}$ avid $\mathrm{M}$ adison \\
\hline & O hio D epartment of Agriculture \\
\hline & 8995 East M ain Street \\
\hline & Reynoldsberg, OH 43068-3399 \\
\hline & (614) $728-6404$ \\
\hline & madison@odant.agri.state.oh.us \\
\hline \multirow[t]{7}{*}{ Pennsylvania } & $\mathrm{N}$ ancy S. H. Richwine \\
\hline & Plant Pathologist Supervisor \\
\hline & Pennsylvania D epartment of Agriculture \\
\hline & 2301 N orth Cameron Street \\
\hline & $\mathrm{H}$ arrisburg, PA 17140-9408 \\
\hline & (717) $772-5223$ \\
\hline & N richwine@pda005.pda.state.pa.us \\
\hline \multirow[t]{6}{*}{ Rhode I sland } & D aniel L awton \\
\hline & DEM Agriculture \\
\hline & 235 Promenade Street \\
\hline & Providence, RI 02908-5734 \\
\hline & (401) 222-2781 \\
\hline & dlawton@doa.state.ri.us \\
\hline \multirow[t]{7}{*}{ South Carolina } & H.D. Jackson \\
\hline & Plant Industry \\
\hline & South Carolina D epartment of Agriculture \\
\hline & 511 Westinghouse Road \\
\hline & Pendleton, SC 29670 \\
\hline & (864) 646-2131 \\
\hline & hjcksn@clemson.edu \\
\hline \multirow[t]{6}{*}{ Virginia } & Phillip Eggborn \\
\hline & Virginia D epartment of Agriculture \\
\hline & P.O. Box 1163 \\
\hline & Richmond, VA 23218 \\
\hline & (804) 786-3515 \\
\hline & vdacsopp@richmond.infi.net \\
\hline \multirow[t]{7}{*}{ West Virginia } & Gary Gibson \\
\hline & West Virginia D epartment of Agriculture \\
\hline & Plant Industries D ivision \\
\hline & 1900 Kanawha Boulevard, East \\
\hline & Charleston, WV 25305-0191 \\
\hline & (304) 558-2212 \\
\hline & gibsong@wvlc.wvnet.edu \\
\hline
\end{tabular}

$R$ ibes immune to both rust races of WPBR?

As mentioned before, the regulated states vary as to their intent to enforce or change regulations ( $T$ able 1,2 ). M ost states have taken a waitand-see approach, wanting to have more data formally presented by pathologistsand ecologistsbeforechanging regulations. Following are some examples of state approaches. $M$ aine strongly believes that their regulation is necessary, and they continue a R ibes reduction program. Vermont has not renewed any regulation, and allows unrestricted R ibes cultivation. New $\mathrm{H}$ ampshire is allowing cultivation of WPBR immune cultivars. M ost states restricting $\mathrm{R}$ ibescultivation would like to update their regulations based on scientific data that answers questions they have listed. The states would like to see their regulations be consistent, and appropriate for the good health of pine and $\mathrm{R}$ ibes plantings. There is interest in developing a list of permissible WPBR immune R ibescultivars to be used by states that choose to maintain restrictions.

\section{Literature cited}

M cKay, S. 1998. White pine blister rust (WPBR) information page. 1 Sept. 1999. $<$ www.cce.cornell.edu/ Columbial smckay/ wpbr.html>. 